\title{
The effect of DCD on nitrate leaching losses from a winter forage crop receiving applications of sheep or cattle urine
}

\author{
R.W. McDOWELL and D.J. HOULBROOKE \\ AgResearch Ltd, Invermay Agricultural Centre, Private Bag 50034, Mosgiel, New Zealand \\ richard.mcdowell@agresearch.co.nz
}

\begin{abstract}
Dicyandiamide (DCD) is an effective mitigation option for decreasing nitrate-nitrogen $\left(\mathrm{NO}_{3}-\mathrm{N}\right)$ losses in drainage water from New Zealand pastures. This study determined the relative effect of DCD on decreasing $\mathrm{NO}_{3}-\mathrm{N}$ losses from simulated sheep or cattle urine patches applied to a winter forage crop. Lysimeters were collected from a site in North Otago (Mottled Fragic Pallic Timaru silt loam). DCD was applied one day following the removal of crop herbage (triticale) and urine was added at rates pertinent to cattle and sheep. Loads of $\mathrm{NO}_{3}-\mathrm{N}$ in leachate during the study period (May 2007 until May 2008) were three times greater from lysimeters receiving cattle urine $(\sim 300 \mathrm{~kg} /$ ha) than those receiving sheep urine. DCD applied to lysimeters that received cattle urine decreased $\mathrm{NO}_{3}-\mathrm{N}$ leaching losses for 4 months after application, resulting in a net $39 \%$ decrease in $\mathrm{N}$ lost during the study. No significant effect was evident when the application of DCD followed sheep urine, suggesting that DCD only offers benefits for intensive cattle systems, but this requires further investigation.
\end{abstract}

Keywords: drainage, lysimeters, urine, nitrate, dicyandiamide, winter forage cropping

\section{Introduction}

Many studies have shown that nutrient losses tend to increase with agricultural intensification (McDowell et al. 2009). For nitrogen (N), the main pathway is leaching, which can then travel via sub-surface flow to surface water or downwards to groundwater. Transfer of $\mathrm{N}$ to surface water can promote unwanted plant or algal growth, while transfer to groundwater can impair use as drinking water. A major source of $\mathrm{N}$ lost is that leached from urine patches as a result of an oversupply of $\mathrm{N}$ relative to plant uptake. Many studies have quantified the loss of $\mathrm{N}$ (largely as nitrate) from cattle urine patches (e.g. Silva et al. 1999), but less work has established losses from sheep grazed land (e.g. Sakadevan et al. 1994).

One of the strategies employed to decrease $\mathrm{N}$ lost by leaching has been the use of dicyandiamide (DCD), which slows the conversion of $\mathrm{N}$ from immobile to mobile (largely nitrate) forms (Monaghan et al. 2009; Di \& Cameron 2002; Slangen \& Kerhoff 1984). Maintaining mineral $\mathrm{N}$ in the soil has also been shown to increase $\mathrm{N}$ availability for plant uptake and decrease nitrous oxide emissions (Di et al. 2007; Moir et al. 2007; Di \& Cameron 2002). However, winter-grazed forage systems are quite different to rotational pasture grazing systems as forage crops are only grazed once or twice a year. Furthermore, grazing traditionally takes place with very high stocking densities and at a time when soil moisture is typically close to or at field capacity, and leaching is likely (Houlbrooke et al. 2009; Drewry \& Paton 2005). Simulation modelling of winter contributions to N losses in the "Bog Burn" catchment of Southland suggested that $c .55 \mathrm{~kg} \mathrm{~N} / \mathrm{ha} / \mathrm{yr}$ could be lost from winter forage crops (Monaghan et al. 2007).

The objective of this paper was to define the loss of $\mathrm{NO}_{3}-\mathrm{N}$ in leachate from lysimeters taken from a winter forage crop and treated with either cattle or sheep urine and with or without DCD.

\section{Materials and Methods \\ Lysimeter collection}

The effectiveness of DCD to decrease $\mathrm{NO}_{3}-\mathrm{N}$ leaching losses from a winter forage crop used lysimeters gathered from the Land-Use Change and Intensification (LUCI) research trial site in Windsor, North Otago (Houlbrooke et al. 2009). The soil type at the site was a Mottled Fragic Pallic Timaru silt loam soil (Hewitt 1998). A triticale winter forage crop (x Triticosecale Wittmack) was direct-drilled in March 2007. Previously, the site had been used for winter crops in 2006 (swede) and 2005 (kale) and a barley silage crop in 2004. Before these crops, the site had been in permanent pasture for more than 20 years. Thirty two PVC lysimeters were collected (15 cm diameter, $24 \mathrm{~cm}$ depth) from the field at the end of April 2007 from sheep- and cattle-grazed and irrigated winter forage crop plots. This was done by placing the lysimeter casing ( $5 \mathrm{~mm}$ thick) on the soil surface and digging around it. This allowed the casing to be pushed down over the soil in incremental steps while avoiding disturbance of the soil monolith. The lysimeters were protected from edge flow effects by the injection of molten petroleum jelly (Shell, Australia) into a gap $(5 \mathrm{~mm})$ between the casing and soil. A thin layer of sand was placed between the soil and PVC end-cap, to prevent soil loss. A hole was drilled in the end cap into which a small quantity of glass wool and 
a nipple was inserted to allow for the collection of leachate.

Shallow lysimeters were chosen to study $\mathrm{N}$ losses due to the practical difficulties associated with measuring $\mathrm{NO}_{3}-\mathrm{N}$ losses on rolling land where drainage is impeded by a near-impermeable layer at $25-30 \mathrm{~cm}$ depth (hydraulic conductivity $<0.1 \mathrm{~mm} / \mathrm{hr}$; R. Paton pers. comm.). In this landscape, $\mathrm{NO}_{3}-\mathrm{N}$ movement is expected primarily via soil interflow within the A-horizon down the rolling landscape toward the toe of the slope. It is acknowledged that this approach will measure a greater quantity of $\mathrm{N}$ leached than deeper lysimeters. However, we argue that deeper lysimeters may underestimate losses at this site by including an impeded drainage layer that would lead to slow drainage or ponding, which may promote $\mathrm{N}$ loss to the atmosphere via denitrification and the production of nitrous oxide. It is also acknowledged that losses via lysimeters will not account for attenuation down the slope.

\section{Management}

The lysimeters were established at the Invermay Agricultural Centre with rainfall protection from late April 2007. The study was operated with lysimeter management reflecting that of the North Otago site including animal grazing, fertiliser timing and application rates, weed control plus rainfall, and irrigation volumes, but not animal treading. Simulated grazing events (removal of forage and application of urine) took place in line with field site operations on the $16^{\text {th }}$ of May and the $27^{\text {th }}$ of July 2007, with either yearling cattle or lambs (Houlbrooke et al. 2009). The lysimeters were fallow from August until late December 2007 when they were replanted with kale in accordance with the crop rotation of the North Otago research site.

The experiment contained eight treatments with four replicates (cattle versus sheep, urine versus non-urine, DCD versus no DCD). A description of management inputs associated with a single simulated grazing event (urine and DCD application) is presented in Table 1. The artificial urine was made in accordance with methodology described by Smith et al. (2005). In summary, lysimeters received urine at rates equivalent to $10 \mathrm{~L} / \mathrm{m}^{2}(0.18 \mathrm{~L} /$ lysimeter $)$ and $3.95 \mathrm{~L} / \mathrm{m}^{2}(0.07 \mathrm{~L} /$ lysimeter) for cattle and sheep, respectively (Haynes \& Williams 1993; de Klein et al. 2003). The concentration of $\mathrm{N}$ in the artificial urine was $6 \mathrm{~g} \mathrm{~N} / \mathrm{L}$ for both cattle and sheep; the change in urine volume provided the difference in urine $\mathrm{N}$ loading rates of $580 \mathrm{~kg} \mathrm{~N} / \mathrm{ha}$ for cattle and $229 \mathrm{~kg} \mathrm{~N} / \mathrm{ha}$ for sheep (Smith et al. 2005; Haynes \& Williams 1993; de Klein et al. 2003). A granular form of DCD was applied in accordance with the manufacturers recommendations at a rate of 15 $\mathrm{kg} \mathrm{DCD} / \mathrm{ha}$ one day after simulated grazing and the application of urine. The same management was applied to all lysimeters for both of the simulated grazing events. Therefore, urine patch treatments received urine $\mathrm{N}$ inputs equivalent to the load from two urine patches during winter grazing. While this represents a worst case scenario for potential leaching losses, it may occur in up to $15 \%$ of the paddock and does offer an amplified scenario for testing the relative effectiveness of DCD for decreasing $\mathrm{N}$ leaching losses.

\section{Sample collection and analysis}

Leachate was collected in response to water inputs (rainfall/irrigation) in containers placed below the lysimeters. After each event, suction was applied to each lysimeter to remove any ponded water between the soil and the end cap to prevent $\mathrm{N}$ losses via denitrification. This additional leachate was bulked with the original leachate samples. All leachates were analysed for $\mathrm{NO}_{3}-\mathrm{N}$ using a standard auto-analyser technique (APHA 1998). Nutrient losses were calculated using the volume of leachate collected and concentration of the leachate. Point-wise data for each sampling date and summary data (mean concentrations and total loads) for the complete sampling period were analysed by ANOVA, fitting terms for the factorial interaction of stock type, urine application and DCD treatment. To understand patterns in $\mathrm{NO}_{3}-\mathrm{N}$ concentrations with time, a REML analysis was used, including splines for relevant terms, with the fixed model as for the ANOVAs along with sampling time and its interactions.

\section{Results and Discussion}

The concentration of $\mathrm{NO}_{3}^{-}-\mathrm{N}$ in leachate from urine treated lysimeters was significantly greater than in leachate from non-urine treated lysimeters with time (Fig. 1). Furthermore, $\mathrm{NO}_{3}-\mathrm{N}$ concentrations were consistently greater $(\mathrm{P}<0.05)$ from lysimeters treated with cattle than sheep urine. The first application of urine (grazing simulation) in mid May 2007 increased the $\mathrm{NO}_{3}-\mathrm{N}$ concentration of leachate collected in late June 2007. The second urine application, in late July 2007, was followed by two drainage events within 10 days of application; no immediate increase in $\mathrm{NO}_{3}-\mathrm{N}$ leachate concentration was observed in these drainage events.

A REML analysis determined that following the first application DCD, the product was effective in decreasing $\mathrm{NO}_{3}-\mathrm{N}$ lost from application of cattle urine for at least 10 weeks before the urine was reapplied. A second application of DCD in response to grazing and urine in winter resulted in a significant decrease in $\mathrm{NO}_{3}-\mathrm{N}$ leached for 4 months (Fig. 1). However, enriched concentrations of $\mathrm{NO}_{3}-\mathrm{N}$ were leached beyond this period. Based on the relationship between temperature and DCD half-life (Kelliher et al. 2008), we estimated half-lives during the period of effectiveness to vary from 110 days in August to 53 days in November in response to mean soil temperatures at $10 \mathrm{~cm}$ depth of $5.0-13.7^{\circ} \mathrm{C}$ 
Table 1 Management inputs associated with a simulated grazing event.

\begin{tabular}{|c|c|c|c|c|c|c|c|c|}
\hline & \multicolumn{2}{|c|}{ Cattle urine } & \multicolumn{2}{|c|}{ Cattle non-urine } & \multicolumn{2}{|c|}{ Sheep urine } & \multicolumn{2}{|c|}{ Sheep non-urine } \\
\hline & DCD & No DCD & DCD & No DCD & DCD & No DCD & DCD & No DCD \\
\hline Urine $\left(L / \mathrm{m}^{2}\right)$ & 10 & 10 & - & - & 4 & 4 & - & - \\
\hline Urine $N(g / L)$ & 6 & 6 & - & - & 6 & 6 & - & - \\
\hline Urine N (kg/ha) & 580 & 580 & - & - & 229 & 229 & - & - \\
\hline DCD (kg/ha) & 15 & - & 15 & - & 15 & - & 15 & - \\
\hline
\end{tabular}

Figure 1 Mean amount of precipitation and leachate and the concentration of $\mathrm{NO}_{3}-\mathrm{N}$ in leachate for each treatment with time. Unfilled symbols signify those treatments with $\mathrm{DCD}$ applied. Black signifies cattle treatments and grey sheep treatments. The arrows indicate when simulated grazing occurred. Only events that caused $>5 \mathrm{~mm}$ of leaching are shown. The significant effect (black crosses) refers only to cattle urine treated lysimeters with and without DCD applied 1 day following urine application.

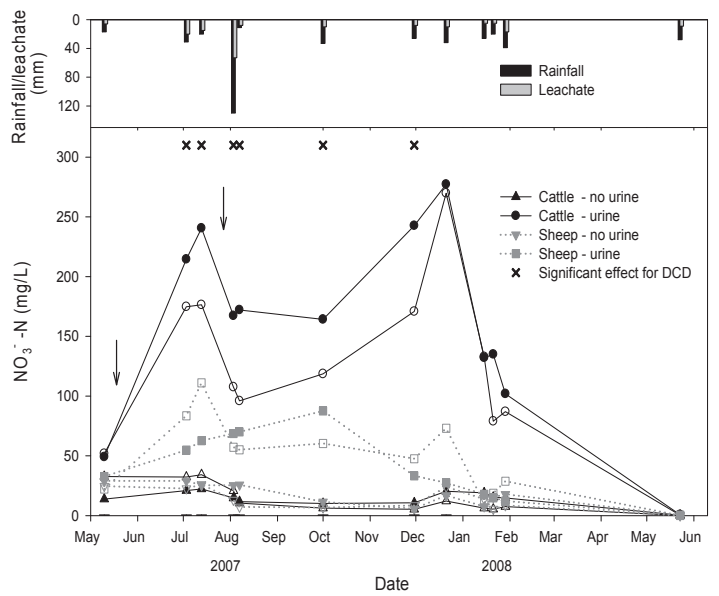

(at Invermay), which may explain the variation in DCD effectiveness. Kelliher et al. (2008) further suggested that the half-life for DCD relates to the expected period of effectiveness, which is, unlikely to be longer than the 4 months measured.

The loads of $\mathrm{NO}_{3}-\mathrm{N}$ lost in leachate over the study period exhibited a significant grazing animal (cattle vs. sheep) effect $(\mathrm{P}<0.001)$, urine effect $(\mathrm{P}<0.001)$, and grazing animal by urine interaction $(\mathrm{P}=0.001)$. Loads of $\mathrm{NO}_{3}-\mathrm{N}$ in leachate over the study period were three times greater from lysimeters receiving cattle urine than those receiving sheep urine, while loads from lysimeters receiving urine applications were six times greater than lysimeters receiving no urine- $\mathrm{N}$ inputs (Table 2). The interaction between grazing animal and urine can be attributed to the significantly greater $\mathrm{NO}_{3}-\mathrm{N}$ loss from cattle than from sheep urine patches. The large loss of $\mathrm{NO}_{3}-\mathrm{N}$ from urine patches compared
Table $2 \quad$ Nitrate-N load lost from each treatment. The least significant difference for the interaction between urine and DCD is also given $\mathrm{P}<0.05$ significance level.

\begin{tabular}{lccc}
\hline Stock type & Urine & DCD & $\begin{array}{c}\mathrm{NO}_{3}-\mathrm{N} \text { load } \\
(\mathrm{kg} / \mathrm{ha})\end{array}$ \\
\hline Cattle & Yes & No & 300 \\
& Yes & Yes & 184 \\
& No & No & 29 \\
& No & Yes & 31 \\
LSD $_{\text {05-urine } \times \mathrm{DCD}}$ & & & 91 \\
Sheep & Yes & No & 98 \\
& Yes & Yes & 82 \\
& No & No & 31 \\
& No & Yes & 22 \\
LSD $_{\text {05-urine } \times \mathrm{DCD}}$ & & & 54 \\
\hline
\end{tabular}

to non-urine areas was expected given the total urine- $\mathrm{N}$ applied (1160 kg/ha for cattle and $458 \mathrm{~kg} / \mathrm{ha}$ for sheep) as a result of two applications, one in May 2007 and one in July 2007. The application of urine patches to the same place can be considered a worst-case scenario given typical field grazing should result in minimal (commonly $<15 \%$ ) urine patch overlap (Haynes \& Williams 1993). Furthermore, the reported differences in $\mathrm{NO}_{3}-\mathrm{N}$ leaching losses between cattle and sheep are expected given $\sim 60 \%$ difference in urine $\mathrm{N}$ deposited per application. The large leaching losses of $\mathrm{N}$ from urine patches has been reported extensively in New Zealand and international literature for grazed pastures (e.g. Silva et al. 1999; Di \& Cameron 2002). Our data confirms a similar effect for winter forage crops, particularly when grazing by cattle.

Overall, the application of DCD decreased $\mathrm{NO}_{3}-\mathrm{N}$ leaching losses from lysimeters that received cattle urine by $39 \%(\mathrm{P}<0.05)$. However, no significant effect was evident when DCD was applied to lysimeters that received sheep urine $(\mathrm{P}=0.223)$. The lack of a response to $\mathrm{DCD}(16 \%$ decrease $)$ for the sheep urine treatment 
was unexpected and requires further consideration. This could include investigation of the effectiveness of DCD relative to a range of $\mathrm{N}$ deposition rates (including the low rate found in sheep), and the degree of replication required to show potential differences.

\section{Conclusions}

Under simulated conditions, leaching losses of $\mathrm{NO}_{3}-\mathrm{N}$ from lysimeters treated with cattle urine were three times greater than from those receiving sheep urine. The application of DCD to cattle urine treated lysimeters decreased $\mathrm{N}$ losses, during the study period, by $39 \%$ compared to lysimeters that had received cattle urine but not DCD. A second application of DCD one day after urine had been applied decreased $\mathrm{NO}_{3}-\mathrm{N}$ leaching losses from the cattle urine treatment for 4 months. This was calculated as close to the longest time possible for effectiveness given the soil and climatic conditions and their effect on DCD decomposition. No significant effect was evident when DCD was applied to lysimeters treated with sheep urine, suggesting the technology should be used for intensive cattle until a better understanding of the behaviour of the inhibitor in intensive sheep grazed systems is gained.

\section{ACKNOWLEDGEMENTS}

This research was funded by the New Zealand Fertilizer Manufacturer's Research Association and the New Zealand Foundation for Research, Science and Technology (contract C02X0304 \& C10X0320). The technical assistance of S. Walker, J. Paton, B. Lumsden, D. Enright and J. Campbell is gratefully acknowledged.

\section{REFERENCES}

APHA. 1998. Standard methods for the examination of water and wastewater: $20^{\text {th }}$ edition. American Public Health Association, American Water Works Association, Water Environment Federation, Washington D.C.

de Klein, C.A.M.; Barton, L.; Sherlock R.R.; Li, Z.; Littlejohn, R.P. 2003. Estimating a nitrous oxide emission factor for animal urine from some New Zealand pastoral soils. Australian Journal of Soil Research 41: 381-399.

Di, H.J.; Cameron, K.C. 2002. The use of a nitrification inhibitor, dicyandiamide (DCD), to decrease nitrate leaching and nitrous oxide emissions in a simulated grazed and irrigated grassland. Soil Use and Management 18: 395-403.

Di, H.J.; Cameron, K.C.; Sherlock, R.R. 2007. Comparison of the effectiveness of a nitrification inhibitor, dicyandiamide, in reducing nitrous oxide emissions in four different soils under different climatic and management conditions. Soil Use and Management 23: 1-9.

Drewry, J.J.; Paton, R.J. 2005. Soil physical quality under cattle grazing of a winter fed brassica crop. Australian Journal of Soil Research 43: 525-531.

Hewitt, A.E. 1998. New Zealand Soil Classification. Manaaki Whenua Press, Lincoln. 133 pp.

Haynes, R.J.; Williams, P.H. 1993. Nutrient cycling and soil fertility in the grazed pasture ecosystem. Advances in Agronomy 49: 119-199.

Houlbrooke, D.J.; Paton, R.J.; Morton, J.D.; Littlejohn, R.P. 2009. Soil quality and plant yield under dryland and irrigated winter forage crops grazed by sheep or cattle. Australian Journal of Soil Research 47: 470-477.

Kelliher, F.M.; Clough, T.J.; Clark, H.; Rys, G.; Sedcole, J.R. 2008. The temperature dependence of dicyandiamide (DCD) degradation in soils: a data synthesis. Soil Biology \& Biochemistry 40: 1878-1882.

McDowell, R.W.; Larned, S.T.; Houlbrooke, D.J. 2009. Nitrogen and phosphorus in New Zealand rivers and streams: the control and impact of eutrophication and the influence of land management. New Zealand Journal of Marine and Freshwater Research 43: 985-995.

Moir, J.L.; Cameron, K.C.; Di, H.J. 2007. Effects of the nitrification inhibitor dicyandiamide on soil mineral $\mathrm{N}$, pasture yield, nutrient uptake and pasture quality in a grazed pasture system. Soil Use and Management 23: 111-120.

Monaghan, R.M.; Wilcock, R.J.; Smith, L.C.; Tikkisetty, B.; Thorrold, B.S.; Costall, D. 2007. Linkages between land management activities and water quality in an intensively farmed catchment in southern New Zealand. Agriculture, Ecosystems and Environment 118: 211-222.

Monaghan, R.M.; Smith L.C.; Ledgard, S.F. 2009. The effectiveness of a granular formulation of dicyandiamide (DCD) in limiting nitrate leaching from a grazed dairy pasture. New Zealand Journal of Agricultural Research 52: 145-159.

Sakadevan, K.; Hedley, M.J.; Mackay, A.D. 1994. An in situ mini lysimeter with a removable ion exchange resin trap for measuring nutrient losses by leaching from grazed pastures. Australian Journal of Soil Research 32: 1389-1400.

Silva, R.G.; Cameron, K.C.; Di, H.J.; Hendry, T. 1999. A lysimeter study of the impact of cow urine, dairy shed effluent, and nitrogen fertiliser on nitrate leaching. Australian Journal of Soil Research 37: 357-369.

Slangen, J.H.; Kerkhoff, P. 1984. Nitrification inhibitors in agriculture and horticulture: a literature review. Fertiliser Research 5: 1-76.

Smith L.C.; Monaghan, R.M.; Ledgard, S.F.; Catto W.D. 2005. The effectiveness of different nitrification inhibitor formulations in limiting nitrate accumulation in a Southland pastoral soil. New Zealand Journal of Agricultural Research 48: 517-529. 